UDC 338.24

JEL Classification: F00, 057

http://doi.org/10.21272/mmi.2019.3-06

Radovan Bacik,

Ph.D., Associate Professor, University of Presov, Slovakia

Jitka Kloudova,

Ph.D., Associate Professor, University of Entrepreneurship and Law, Czech Republic

Jaroslav Gonos,

Ph.D., University of Presov, Slovakia

Viera Ivankova,

University of Presov, Slovakia

\title{
MANAGEMENT OF COMPETITIVENESS AND ECONOMIC PERFORMANCE BASED IN THE V4 COUNTRIES
}

Abstract. The economic condition and competitiveness is currently a highly discussed issue and it is necessary to confront individual countries. In a period characterized by economic dynamics, economic growth, the sustainability of economic development, it is common that most countries are concerned with the study of indicators that can help them to understand their economic situation. This paper focuses on the competitiveness and economic performance of the V4 countries based on two selected indicators - Global Competitiveness Index and Gross Domestic Product growth rate in the period from 2002 to 2016. The countries of the Visegrad Group do not only share a common Central European space, apart from geographic location, but they are also linked with history, culture, values, priorities and interests to strengthen stability in the Central European region. The aim of this study is to assess the development of the V4 economies and to define the degree of homogeneity of the Global Competitiveness Index and the rate of GDP growth between Slovakia, the Czech Republic, Hungary and Poland. To meet the main goal, selected indicators were subjected to an analysis of their development in the set period and their mutual confrontation was carried out. For analysis of variances, we used statistical method ANOVA. Countries of Visegrad Group are linked by significant factors from social areas, but each country faces different economic problems, which determines their economic status and position in the world. Based on the results, the Czech Republic records the most significant differences in the $\mathrm{GCl}$ index compared to other V4 countries. The study agrees with the arguments that the Czech Republic is the most successful country within the Visegrad Group. The benefit of the article reflects the perception of the V4 countries from an economic point of view, which is not conditioned by the common characteristics of this group. The analysis absorbs possible skewed speculation and encourages further research that may be dealt with in the future by other macroeconomic indicators within the Visegrad Group.

Keywords: competitiveness, economic performance, GCl, GDP, Visegrad Group, ANOVA.

Introduction. Competitiveness of the economy is currently a highly discussed category. It is widely known that some countries are more advanced some are less advanced. There are significant disparities between countries that also reflect macroeconomic indicators, such as the Global Competitiveness Index $(\mathrm{GCl})$ and the Gross Domestic Product (GDP) growth rate. The article offers an interesting view of these indicators within the countries belonging to the Visegrad Group. The Visegrad Group (V4) is an informal grouping of four Central European countries - Slovakia, the Czech Republic, Hungary and Poland. This is an informal regional structure of the four EU and NATO member states, which claim the same values (Visegrad Group, 2017). They have a common history, culture and geographical position. This may lead to the idea that even the competitiveness and economic growth of these countries can achieve the same economic outcomes, but on the other hand, we are talking about countries whose economies stand on different operational pillars. The article has the following structure. The first part of the article defines the theoretical framework of the key terms of the given issue with the special focus at the Competitiveness Index of $\mathrm{GCl}$ and GDP indicator. The second part describes the methodology and describes used

Cite as: Bacik, R., Kloudova, J., Gonos, J., \& Ivankova, V. (2019). Management of Competitiveness and Economic Performance Based in the V4 Countries. Marketing and Management of Innovations, 3, 73-88. http://doi.org/10.21272/mmi.2019.3-06 

V4 Countries

statistical methods for data analysis. The main part of the paper called Results is devoted to the problematics of the development of the competitiveness index and growth rate of the V4 Countries for 2002-2016 and the analysis of the competitiveness index of the homogeneity rate and GDP growth rate. In the conclusion, a brief discussion on the importance of economic performance monitoring is offered from the point of view of these two selected indicators and the assessment of the economic condition of the four countries belonging to the Visegrad group.

The article has the following structure. The first part of the article defines the theoretical framework of the key terms of the given issue with the special focus at the competitiveness index of GCI and GDP indicator. The second part describes the methodology and describes used statistical methods for data analysis. The main part of the paper called Results is devoted to the problematic of the development of the competitiveness index and growth rate of the V4 countries for 2002-2016 and the analysis of the Global Competitiveness Index of the homogeneity rate and GDP growth rate. In the conclusion, a brief discussion on the importance of economic performance monitoring is offered from the point of view of these two selected indicators and the assessment of the economic condition of the four countries belonging to the Visegrad Group.

Literature Review. Nowadays, we are often confronted with the concept of macroeconomic competitiveness, which expresses the capacity of the economy to create, use and sell outcomes in the global competition so that citizens' welfare grows sustainably to other economies (Tkacova et al.2017; Slany, 2006). When assessing competitiveness from a macroeconomic point of view, it is mainly the assessment of the economy according to its assumptions and the ability to compete in international competition based on its economic strength and the condition (Mokrasova,2008).

Many authors discussed the study of the competitiveness of economies, from the domestic authors we can mention, for example, Bondareva and Tomcik (2015) who applied the Global Competitiveness Index (GCl) within Slovakia and the Czech Republic. Results show that the strong pillars of the Slovak economy include health care and basic education of the population; on the other hand, the disadvantage of Slovakia is mainly the low efficiency of the work of state institutions and the insufficient innovation potential. Gavurova et al. $(2016,2018)$ agree with that conclusion. Kotaskova and Rozsa (2018) studied the impact of selected factors on the quality of business environment assessment and the competitiveness of the Czech Republic and Slovakia. Spirkova et al. (2019) and Kocisova et al. (2019) evaluated the competitiveness of the state in relation to the healthcare in the linkage with the used type of fueling in the selected regions and wound a strong dependency of the state competitiveness and regulation in this field.

Dudas (2012) focused on the development of the competitiveness of the V4, based on two main indices - the Global Competitiveness Index and the World Competitiveness Index. In this content Simionescu et al. (2017) state the middle and long-term slowdown in growth dynamics could bring serious social and political problems for V4 countries and Romania. It would threaten reaching benefits from the potential of convergence process with the developed countries of the European Union. As a result, the V4 economies and Romania should find solutions to achieving a sustainable growth that is associated with an improvement of their international competitiveness. Simionescu (2016) examines in detail the competitiveness of the Romanian economy and states that competitiveness is not based on innovation and investment in human capital. Kljucnikov et al. (2018) studied the impact of the sharing economy models in the business environments and found their substantial impact on the competitiveness that required some an accurate regulative approach from the state.

The publication by Ivanova and Masarova (2018) provides a review on this subject using the Global Competitiveness Index and Gross Domestic Product per capita. In order to evaluate the performance of the Visegrad countries, the authors used scoring method. Based on the scoring method results, they note that within the V4 countries Czech Republic is the most successful country. Kordalska and Olczyk's 

V4 Countries

(2016) study tests the relationship between the $\mathrm{GCl}$ and the economic growth rate by using a panel Granger causality analysis based on annual data for 114 countries divided into five groups by income criteria and covering the period 2006-2014. Authors confirm a strong unidirectional causality among the countries analysed, i.e. GDP growth causes global competitiveness. Additionally, they find that the GCI is success full in predicting economic growth for the majority low income and OCED high-income counties. Klikova (2015) realized the study with the aim to determine how globalisation affects the competitiveness of the economy and to verify the assumption that competitiveness increases with the degrees of an economy's globalisation. The study used the example of the V4 countries. Authors take that the higher degrees of globalisation an economy achieves, the more competitive it becomes has been confirmed only partially.

Bartalosova (2015) examined the importance of the global index of competitiveness of individual countries of V4 when compared to the EU. The paper by Ivanova et al. (2015) offers the competitiveness analysis of the geopolitical regional association of $V-4$ countries by means of such tools as the Global Competitiveness Index and the Prosperity Index and defining their extent of the impact on the competitiveness enhancement of the EU as a single entity of the global economy. The study by Bucher (2018) reveals a high correlation between a country's rating for the Global Competitiveness Index and the Human Development Index, the gross domestic product per capita, the level of gender inequality, and the competitiveness of the travel and tourism industry. Also, authors such as Soosova (2014), Habanik and Hostak (2014), Palkovic et al. (2015), Kiselakova et al. (2018), Despotovic et al. (2016) realized the studies focused on competitiveness. Opreana and Mihaiu (2011), who focused on the analysis of the competitiveness of the European Union, according to them the main objective was to analyze the EU's competitiveness based on factors influencing the overall competitiveness of the EU, such as public debt, budget deficit or the competitiveness of national economies. Podobnik et al. (2012) analyzed the competitiveness and the wealth of the country based on the Corruption Perceptions Index (CPI) and the Global Competitiveness Index (GCI). In this paper, we will analyze the competitiveness of V4 countries based on GCl and GDP.

A key factor of the states' increasing competitiveness is assumed to be the innovation performance of enterprises, which is projected through innovative business processes into the innovation performance of the economy as a whole (Ivanova and Cepel, 2018).

Competitiveness Index of GCl. The World Economic Forum (WEF) has been dealing with the competitiveness of the countries for more than three decades. Since 1979, it has published every year a "Global Competitiveness Report», which assesses the factors of sustained economic growth and the long-term prosperity of individual countries of the economy (Gordiakova 2011). For the evaluation of global competitiveness, we used the Global Competitiveness Index (GCl). This index assesses the competitiveness of the economy based on three sub-indices (basic requirements, efficiency incentives and innovation and sophistication factors). These sub-indices include pillars, on what the individual economies were rated.

The World Economic Forum identifies these pillars:

1. Institutions or more precisely the quality of public institutions: The quality of the institutional environment can be judged from the point of view of the quality of the state administration and the efficiency of the enterprises or markets. In this pillar, the sub-factors such as proprietary rights, intellectual property protection, ethical behaviour of companies, as well as the independence of the judiciary from the influence of government organizations and companies, as well as the degree of the corruptive environment are assessed.

2. Infrastructure: Infrastructure affects the competitiveness of the countryside as it reduces the distance between regions and integrates national trade. These include indicators such as the quality of the road, railway, air and river transport and energy supply. 
R. Bacik, J. Kloudova, J. Gonos, V. Ivankova. Competitiveness and Performance Based on the Economic Indicators in the V4 Countries

3. Macroeconomic environment or more precisely the macroeconomic stability: This pillar evaluates macroeconomic aggregates as the overall level of Gross Domestic Product (GDP), growth rate, unemployment and development, inflation, stabilization economic policy, and the foreign relations of the country.

4. Health care and basic education: A healthy and educated workforce is a significant asset and, finally yet importantly, an important factor influencing the competitiveness of the country. Poor health status of workers leads to significant losses, as there is a frequent absence of sick employees or a decrease in their performance.

5. Higher education and training: This includes, for example, the quality of school management and the quality of education in mathematics and exact sciences, the availability of specialized research and training facilities, as well as access to the Internet in schools etc.

6. Goods market efficiency: This group includes factors such as the level of competition and customer orientation, the effectiveness of an anti-trust policy, but also, for example, the number of procedures needed to start a business.

7. Labour market efficiency: Questions concerning employment/unemployment, payment terms, employee/employer relationships, as well as worker productivity issues also fall into this category.

8. Development of the financial market: This group considers, for example, the degree of borrowing from the bank, the availability of financial services or the availability of risk capital.

9. Technological readiness, which means the ability of economists to absorb new knowledge in technology and to use new technological processes, leading to an increase in country productivity. Indicators such as the availability of modern technologies and the ability to use them by companies, the use of the Internet by the population and other indicators related to the use or availability of information technologies.

10. Market size: This is primarily about assessing the size of the domestic and foreign markets and exporting products from the country.

11. Competitiveness of companies - factors such as the quantity and quality of domestic suppliers, the usefulness of marketing, the nature of competitive advantage in companies operating in the country etc.

12. Innovation, more precisely the innovation potential - for assessing this component of the country's competitiveness, for example, the innovative capacities of companies, the quality of scientific and research institutions, the level of investment in research and development, but also the availability of scientists and engineers in the country and the number of registered patents are considered (Bondareva, Tomcik 2013).

It is important to remember that these twelve pillars do not act independently but complement each other. Poor results in one pillar often have a negative impact on other areas. For example, an educated and trained workforce and sufficient funding are a prerequisite for the use of new technologies. New technologies contribute to creating new product and service innovation. Although all pillars are aggregated into one index, each pillar is measured separately (Schwab 2011).

It is important to remember that these twelve pillars do not act independently but complement each other. Poor results in one pillar often have a negative impact on other areas. For example, an educated and trained workforce and sufficient funding are a prerequisite for the use of new technologies. New technologies contribute to creating new product and service innovation. Although all pillars are aggregated into one index, each pillar is measured separately (Schwab 2011).

GDP indicator. The result and a presumption of the country's competitiveness is the long-term sustainable economic growth, which conditions the growth of the economic level. The most important indicator in this area is the Gross Domestic Product. Samuelson and Nordhaus (2007) evaluate the gross domestic product as the most comprehensive measure of total national output and input of goods 

V4 Countries

and services. Baranik (2003) considers the GDP indicator to be the decisive magnitude of the economy, which has an irreplaceable position among macroeconomic indicators. The author also lists other GDP characteristics, such as:

- the gross domestic product most closely reflects the development, level and state of the economy,

- stating factually what society and economy can consume,

- is the monetary expression of the product, which also affects the volume of funding in the economy,

- participates in the development of employment and determines it,

- participates in inflation and affects it,

- affects the volume of exports and imports and determines it,

- participates the capital market, operates on it,

- the resources that the economy and society have are being diverted from GDP.

Until now, the GDP indicator is considered one of the most appropriate indicators for measuring the country's performance, governments and various institutions use it to assess the state of the economy, often used to assess the standard of living of the population, which is not very correct. Kotulic (2011) in his article summed up shortcomings, more precisely the uncertainties and limitations of the indicator, such as the shadow economy, domestic work, leisure time, insensitivity to social value and the quality of goods, the environment and natural resources, the problem of the new economy or the problem of perceiving human happiness and living standards. It should be noted, however, that despite the shortcomings noted, the GDP indicator is the most used indicator of the performance evaluation of the economy.

Methodology and research methods. The primary objective of the article is to assess the development of theV4 economies and to define the degree of homogeneity of the Global Competitiveness Index and the rate of GDP growth between Slovakia, the Czech Republic, Hungary and Poland. For the analysis, we used statistical data obtained from WEF and Eurostat databases from 2002 to 2016. For the assessment of the performance of the V4 economies, we used the macroeconomic indicator of GDP growth rate. The competitiveness of the countries is represented by the GCl index. The individual statistics corresponding to the $\mathrm{GCl}$ index and GDP growth rate are dependent variables. The countries of the Visegrad Group (SK, CZ, PL, HU) represent independent variables. The time series were not taken into consideration because the data are cross-sections. In order to reach the goal, we formulate the research question and the main hypotheses based on it:

Research question: Is there a difference between the V4 countries in terms of the homogeneity of the Global Competitiveness Index and GDP growth rate?

H.1: We expect a significant difference in the output of the Global Competitiveness Index between individual V4 countries.

H.2: We expect a significant difference in the GDP growth rate between individual V4 countries.

In the article, we used basic scientific methods such as observation method, analysis, synthesis, induction, deduction, comparison method, generalization applied to the object of investigation. Other methods used include the ANOVA statistical method. Analysis of Variances examines the homogeneity of the interval variable on at least three nominal variables (factors), which results in the discovery of the existing variability between the variables. ANOVA examines whether the differences between group diameters are only random or statistically significant. Before applying the variance analysis, three conditions had to be fulfilled, namely the normality condition, the exclusion of extreme values and the homogeneity of variance variables. Once all the conditions were met, it was possible to use the ANOVA method, which was followed by a Bonferroni test that identifies the place of the existing variance. 
R. Bacik, J. Kloudova, J. Gonos, V. Ivankova. Competitiveness and Performance Based on the Economic Indicators in the V4 Countries

Results. Development of the Global Competitiveness Index and Growth Rate of the V4 Countries for 2002-2016. The World Economic Forum in the Global Competitiveness Report publishes the Global Competitiveness Index (GCl) annually, since 1979. The composition of this index is based on the assumption that the competitiveness of the country is due to the effects of several factors, including 12 pillars divided into three groups. The GDP growth rate or economic growth is a relative increase, which reflects the percentage of absolute GDP growth over the period and the level of real product achieved in the previous period. For this reason, it is the reason for the indicator is pointing to the economic condition of the country.

Table 1. Global Competitiveness Index and Gross Domestic Product growth rate of V4 countries for the period 2002-2016

\begin{tabular}{|c|c|c|c|c|c|c|c|c|}
\hline & \multicolumn{2}{|c|}{ Slovakia } & \multicolumn{2}{c|}{ Czech republic } & \multicolumn{2}{c|}{ Hungary } & \multicolumn{2}{c|}{ Poland } \\
\hline Year & GCI & $\begin{array}{c}\text { GDP } \\
\text { Growth } \\
\text { Rate (\%) }\end{array}$ & GCI & $\begin{array}{c}\text { GDP } \\
\text { Growth } \\
\text { Rate (\%) }\end{array}$ & GCI & $\begin{array}{c}\text { GDP } \\
\text { Growth } \\
\text { Rate (\%) }\end{array}$ & GCI & $\begin{array}{c}\text { GDP } \\
\text { Growth } \\
\text { Rate (\%) }\end{array}$ \\
\hline 2002 & 4,20 & 4,8 & 4,26 & 2,0 & 4,63 & 4,5 & 3,98 & 1,4 \\
\hline 2003 & 4,23 & 4,6 & 4,48 & 3,6 & 4,15 & 3,8 & 4,15 & 3,6 \\
\hline 2004 & 4,43 & 5,0 & 4,55 & 4,5 & 4,56 & 4,9 & 3,98 & 5,1 \\
\hline 2005 & 4,31 & 6,4 & 4,42 & 6,4 & 4,38 & 4,4 & 4,00 & 3,5 \\
\hline 2006 & 4,60 & 8,5 & 4,70 & 6,9 & 4,50 & 3,8 & 4,30 & 6,2 \\
\hline 2007 & 4,53 & 10,8 & 4,66 & 5,5 & 4,49 & 0,4 & 4,38 & 7,0 \\
\hline 2008 & 4,44 & 5,7 & 4,57 & 2,7 & 4,35 & 0,8 & 4,28 & 4,2 \\
\hline 2009 & 4,40 & $-5,5$ & 4,61 & $-4,8$ & 4,22 & $-6,6$ & 4,28 & 2,8 \\
\hline 2010 & 4,30 & 5,1 & 4,66 & 2,3 & 4,21 & 0,7 & 4,32 & 3,6 \\
\hline 2011 & 4,24 & 2,8 & 4,56 & 2,0 & 4,32 & 1,8 & 4,50 & 5,0 \\
\hline 2012 & 4,18 & 1,5 & 4,52 & $-0,8$ & 4,36 & $-1,7$ & 4,46 & 1,6 \\
\hline 2013 & 4,14 & 1,4 & 4,51 & $-0,5$ & 4,30 & 1,9 & 4,46 & 1,3 \\
\hline 2014 & 4,10 & 2,5 & 4,43 & 2,7 & 4,24 & 3,7 & 4,45 & 3,3 \\
\hline 2015 & 4,14 & 3,6 & 4,53 & 4,5 & 4,28 & 2,9 & 4,48 & 3,6 \\
\hline 2016 & 4,22 & 4,7 & 4,69 & 2,3 & 4,25 & 2,0 & 4,49 & 2,8 \\
\hline
\end{tabular}

Source: developed by the authors from WEF and Eurostat databases.

The individual figures for the Global Competitiveness Index and GDP growth rates for the V4 countries over the last 15 years are shown in Table 1. Confronting each of the displayed values provides a view of the competitiveness score that individual countries have acquired within the time scale as well as their rate of economic growth. Specifically, the statistical data represented by the final numerical value, i.e. the calculation of the $\mathrm{GCl}$ is based on the gradual aggregation of the results; from the level of the variables (lowest level) to the overall GCl score (the highest level). Table 1 also shows the percentage of GDP growth rates, which shows the development of these values for the Visegrad Four countries in the last 15 years. This indicator shows a change in the real gross domestic product of the analyzed countries. The positive value refers to the GDP growth compared to the previous year, which is a positive development. In order to determine the growth of the economy's performance, this indicator is desirable for a continuous increase in values. 


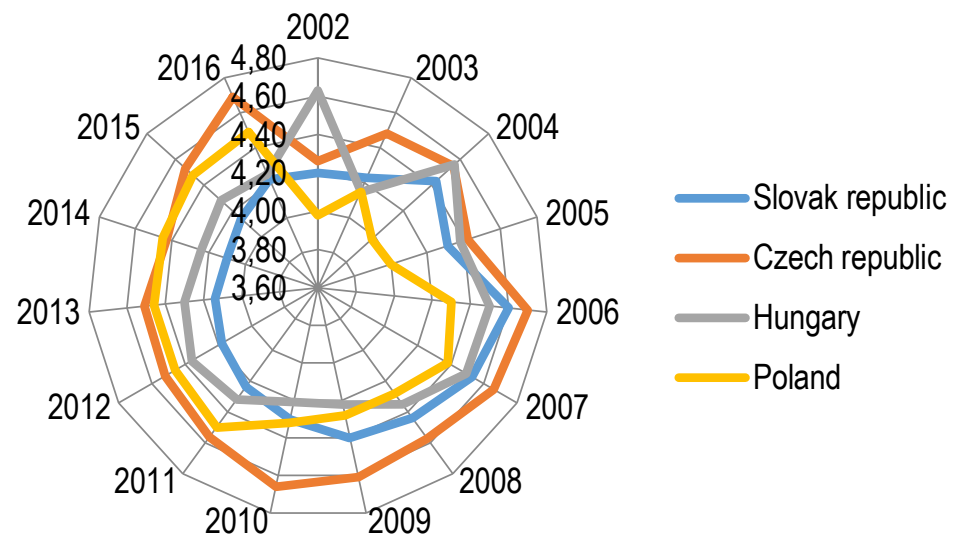

\section{Figure 1. Development of the Global Competitiveness Index of the V4 countries for the period 2002-2016}

Source: developed by the authors

Figure1 illustrates the development of $\mathrm{GCl}$ index values over the past 15 years. We see that the Czech Republic is the leader of the Visegrad Four countries. It is possible to record a phenomenon in the form of a balanced trend of values for the Czech Republic, especially after joining the EU. The Czech Republic in 2016 occupied the 31st place in the total ranking of the countries for which the index is listed.

On the other hand, Slovakia, which has reached the 67th place of the $\mathrm{GCl}$ index in the last year, is on the opposite side of the V4 countries' confrontation. Paradoxically, the trend after joining the EU, with the exception of the last three years, is negative.

The trend for Hungary as well as for Poland is mainly similar, especially considering the joining to the $\mathrm{EU}$, but Poland is doing better in this confrontation, as evidenced by its position in the last year in the 41 st place while Hungary occupied the 63st place.

The importance of the index and scores of the selected countries may be a signal to potential investors who are considering a country where they are winning when deciding on the location of a new production or service project. The most problematic areas of the monitored countries, highlighted by the global competitiveness report over the recent years, are the perceptions of the deteriorating functioning of the state, especially in the areas of corruption, bureaucracy, justice and education. These areas can be seen as key areas for creating and maintaining a functioning business environment. From the neighbouring countries, Austria is on the top, occupying the 23rd place, which can be an inspiration because it is a Central European country.

As it was written, one of the significant periods for monitoring the trend of GDP growth was the accession to the EU. The V4 countries in 2004 joined the European Union and, of course, had a positive expectation that this significant step would be reflected, among other things, in a stronger economic climate. The graphical representation shows that for Slovakia, the Czech Republic and Poland, it was a successful period and it is possible to conclude and agree with these positive expectations. As the growth rate of GDP in these countries shows a rising trend after joining the EU, for one year in the case of Poland. The Czech Republic's joining to the EU has been relatively successful, as can be seen from the figure and from the rising trend after 2004. Hungary was in the opposite situation because its GDP growth rate shows a negative trend. 
R. Bacik, J. Kloudova, J. Gonos, V. Ivankova. Competitiveness and Performance Based on the Economic Indicators in the V4 Countries

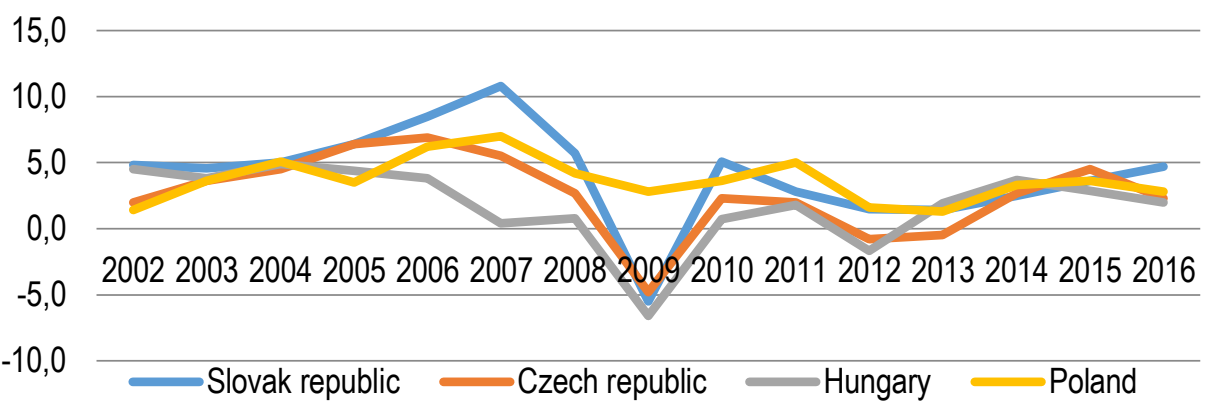

Figure 2. GDP growth rate of V4 countries for the period 2002-2016 (in \%)

Source: developed by the authors

For the V4 countries, a relatively high fiscal deficit was characterized in this period with a view to consolidating it over the long term due to rapid economic growth. However, consolidation was conditioned by the political will to implement structural reforms whose social impact in the medium term has been unfavourable for the population. The common feature for the V4 countries was the current account deficit in 2004, which was a trade deficit (mainly Poland and Slovakia) and a negative balance of revenue (especially the Czech Republic and Hungary), which was related to the repatriation of profits from foreign investment to these countries (Financial Stability Report 2005).

In identifying trends in GDP growth rates for V4 countries, another fact can be identified, namely a sharp decline in growth rates for all the countries mentioned above, mainly after 2008, when the first impacts of the economic crisis emerged. The V4 economies had to respond adequately and eliminate these impacts since the escape from this direct global economic crisis was not in their power. The economic crisis has triggered shocks that have led to a decline in performance in countries. Following years has been a critical period. The V4 economies managed to stabilize the situation, and in subsequent periods, the levels of growth rates gradually returned to roughly the same levels before the economic crisis.

Analysis of the GCl index of the homogeneity rate and GDP growth rate

The following part of the analysis is focusing on defining the degree of homogeneity of the Global Competitiveness Index and the rate of GDP growth rate between the V4 countries. Collected variables corresponding to the V4 Global Competitiveness Index were subjected to a normality test as the first condition. Due to fewer observations, we decided to use the Kolmogorov - Smirnov test (K-S test), which is used in case the random selection comes from a division with a distribution function. In order to perform the test, we formulated the $\mathrm{H}_{0}$ hypothesis and the $\mathrm{H}_{1}$ hypothesis:

$\mathrm{H}_{0}$ : The analyzed variables are in the normal statistical division.

$H_{1}$ : The analyzed variables are not in normal statistical division.

Table 2.Tests of normality - $\mathrm{GCl}$

\begin{tabular}{|c|c|c|c|c|}
\hline & \multicolumn{4}{|c|}{ Kolmogorov-Smirnova } \\
\hline \multirow{5}{*}{ Global Competitiveness Index } & & Statistic & df & Sig \\
\hline & SK & 0.181 & 15 & 0.199 \\
\hline & $\mathrm{CZ}$ & 0.122 & 15 & $0.200^{\star}$ \\
\hline & $\mathrm{PL}$ & 0.190 & 15 & 0.150 \\
\hline & $\mathrm{HU}$ & 0.146 & 15 & $0.200^{*}$ \\
\hline
\end{tabular}

Source: developed by the authors. 
Based on the results shown in Table 2, we state that the significance of each surveyed country reaches more than 0.05 , which results in our acceptance of the $\mathrm{H}_{0}$ hypothesis and the recommendation to reject the $\mathrm{H}_{1}$ hypothesis. In this sense, the normality condition is considered fulfilled and we confirm the normal statistical division of the random variable.

In connection with the fulfillment of the second condition, we have decided to exclude the occurrence of extreme values within the collected data. The following box plot figure helps to show this.

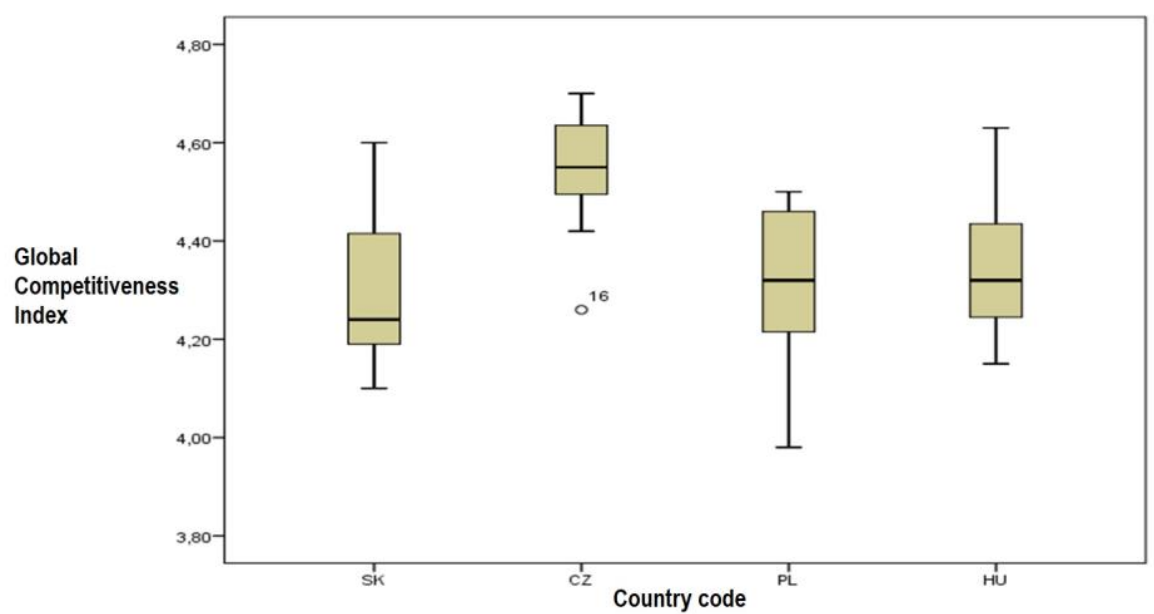

Source: developed by the authors

Figure 3. Boxplot-GCI

Looking at the box plot chart (Figure 3), we note that there is no extreme value within the selected variables to fulfil the second condition. The only outlying value is observed in the Czech Republic, but it is not an extreme value. In the following investigations, we will also consider outlying values.

To meet the third condition, we used a variable homogeneity test to identify whether the variability of variables is the same or different. In this sense, we formulated the $\mathrm{H}_{0}$ and $\mathrm{H}_{1}$ hypotheses.

$\mathrm{H}_{0}$ : There are no significant differences in variance of the analyzed variables, i.e. we consider the variance to be equal.

$\mathrm{H}_{1}$ : There are significant differences in variance of the analyzed variables, i.e. we consider the variance not to be equal.

Table 3.Test of homogeneity of variances - GCI

\begin{tabular}{|c|c|c|c|}
\hline \multicolumn{4}{|c|}{ Global Competitiveness Index } \\
\hline Levene & & & \\
\hline Statistic & df1 & df2 & Sig. \\
\hline 1.427 & 3 & 56 & 0.244 \\
\hline
\end{tabular}

Source: developed by the authors

The other condition for the application of the ANOVA method and therefore the homogeneity of the variance was verified in the previous Table 3 . Since the significance is greater than the value of 0.05 , we recommend accepting the $\mathrm{H}_{0}$ hypothesis and reject the $\mathrm{H}_{1}$ hypothesis. The variance of the analyzed 
R. Bacik, J. Kloudova, J. Gonos, V. Ivankova. Competitiveness and Performance Based on the Economic Indicators in the V4 Countries

variables is considered to be equal and therefore the last condition of homogeneity of variance is considered to be fulfilled. This allows us to apply the variance analysis.

By applying the ANOVA method, it is possible to define a significant difference in the $\mathrm{GCl}$ index between the $\mathrm{V} 4$ countries. For this purpose, we formulated the hypotheses $\mathrm{H}_{0}$ and $\mathrm{H}_{1}$ :

$\mathrm{H}_{0}$ : There are no significant differences in the $\mathrm{GCl}$ index among the V4 countries.

$\mathrm{H}_{1}$ : There are significant differences in the $\mathrm{GCl}$ index among the V4 countries.

Table 4. Analysis of variances - GCI

\begin{tabular}{|c|c|c|c|c|c|}
\hline \multicolumn{7}{|c|}{ ANOVA - Global Competitiveness Index } \\
\hline & Sum of Squares & df & Mean Square & F & Sig. \\
\hline Between Groups & 0.608 & 3 & 0.203 & 8.781 & 0.000 \\
\hline Within Groups & 1.292 & 56 & 0.023 & & \\
\hline Total & 1.900 & 59 & & & \\
\hline
\end{tabular}

Source: developed by the authors

It is evident from Table 4 that the significance between groups is 0 , which is less than 0.05 . For this reason, we reject the $\mathrm{H}_{0}$ hypothesis and accept the $\mathrm{H}_{1}$ hypothesis. The $\mathrm{p}$ value-confirm that there is a significant difference between the analyzed variables, so we can identify statistically significant differences in the $\mathrm{GCl}$ index between Slovakia, the Czech Republic, Poland and Hungary.

In order to identify individual differences of the V4 countries, we decided to use the Bonferroni test, which supports the finding achieved by the ANOVA method. The Bonferroni test examines the different diameters of the countries by means of their differences. The test results are shown in Table 5.

Table 5. Bonferroni test (post hoc) - GCI

\begin{tabular}{|c|c|c|c|c|c|c|}
\hline \multirow{2}{*}{\multicolumn{2}{|c|}{$\begin{array}{l}\text { Country code } \\
\text { (I) }\end{array}$}} & \multirow{2}{*}{$\begin{array}{c}\text { Mean } \\
\text { Difference } \\
(\mathrm{I}-\mathrm{J}) \\
\end{array}$} & \multirow[b]{2}{*}{ Std. Error } & \multirow[b]{2}{*}{ Sig. } & \multicolumn{2}{|c|}{ Interval } \\
\hline & & & & & $\begin{array}{l}\text { Lower } \\
\text { Bound }\end{array}$ & $\begin{array}{l}\text { Upper } \\
\text { Bound }\end{array}$ \\
\hline \multirow{3}{*}{ SK } & $\mathrm{CZ}$ & $-0.24600^{*}$ & 0.05547 & 0.000 & -0.3977 & -0.0943 \\
\hline & $\mathrm{PL}$ & -0.00333 & 0.05547 & 1.000 & -0.1551 & 0.1484 \\
\hline & $\mathrm{HU}$ & -0.05200 & 0.05547 & 1.000 & -0.2037 & 0.0997 \\
\hline \multirow{3}{*}{$\mathrm{CZ}$} & SK & $0.24600^{*}$ & 0.05547 & 0.000 & 0.0943 & 0.3977 \\
\hline & $\mathrm{PL}$ & $0.24267^{*}$ & 0.05547 & 0.000 & 0.0909 & 0.3944 \\
\hline & $\mathrm{HU}$ & $0.19400^{*}$ & 0.05547 & 0.006 & 0.0423 & 0.3457 \\
\hline \multirow{3}{*}{ PL } & SK & 0.00333 & 0.05547 & 1.000 & -0.1484 & 0.1551 \\
\hline & $\mathrm{CZ}$ & $-0.24267^{*}$ & 0.05547 & 0.000 & -0.3944 & -0.0909 \\
\hline & $\mathrm{HU}$ & -0.04867 & 0.05547 & 1.000 & -0.2004 & 0.1031 \\
\hline \multirow{3}{*}{$\mathrm{HU}$} & SK & 0.05200 & 0.05547 & 1.000 & -0.0997 & 0.2037 \\
\hline & $\mathrm{CZ}$ & $-0.19400^{*}$ & 0.05547 & 0.006 & -0.3457 & -0.0423 \\
\hline & $\mathrm{PL}$ & 0.04867 & 0.05547 & 1.000 & -0.1031 & 0.2004 \\
\hline
\end{tabular}

Source: developed by the authors

By comparing the differences between the country indices, we have found that the Czech Republic records are the most significant differences in the $\mathrm{GCl}$ index compared to other V4 countries. This statement shows the achieved value of the signification of 0.000 when comparing the Czech Republic with Slovakia and Poland and the value of the significance of 0.006 when comparing the Czech Republic 

V4 Countries

with Hungary. The significance value less than 0.05 tells us the existence of differences within the analyzed variables.

In any case, the comparison of the Czech Republic with other countries can capture its higher average index against the $\mathrm{GCl}$ index of the other countries of the Visegrad Group. This is shown in the following graphical representation of the average indices of Slovakia, the Czech Republic, Poland and Hungary, where the Czech Republic differs significantly from the average of the other three countries.

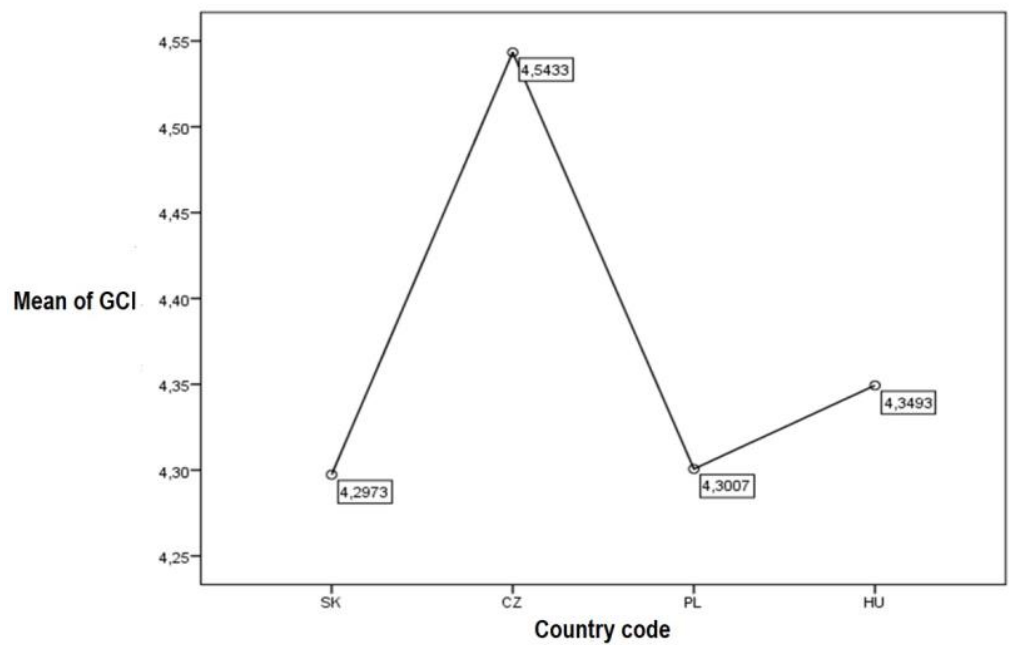

Figure 4.Mean of $\mathrm{GCl}$ of the V4 countries in the period 2002-2016

Source: developed by the authors

In the following part of the analysis, we looked at the assessment of the economic performance factor, where we focused on the GDP growth rate of the analyzed countries of the Visegrad Group. Different statistical data corresponding to the growth rate of GDP has been subjected to the three conditions that need to be met. In this case for the normality test, we decided to use Kolmogorov Smirnov test (K-S test). In order to perform the test, we formulated the $\mathrm{H}_{0}$ and the $\mathrm{H}_{1}$ hypotheses:

$\mathrm{H}_{0}$ : The analyzed variables are in the normal statistical division.

$H_{1}:$ The analyzed variables are not in the normal statistical division.

Table 6. Tests of normality - GDP growth rate

\begin{tabular}{|l|c|c|c|c|}
\hline & \multicolumn{4}{|c|}{ Kolmogorov-Smirnov } \\
\hline \multirow{4}{*}{ GDP growth rate } & & Statistic & df & Sig. \\
\cline { 2 - 5 } & SK & 0.160 & 15 & 0.200 \\
\cline { 2 - 5 } & CZ & 0.218 & 15 & 0.053 \\
\cline { 2 - 5 } & PL & 0.183 & 15 & 0.190 \\
\cline { 2 - 5 } & HU & 0.183 & 15 & 0.189 \\
\hline *. This is a lower bound of the true significance \\
\hline a. Lilliefors Significance Correction \\
\hline
\end{tabular}

Source: developed by the authors

Based on K-S test outputs, we can state that in all cases the value of signification is greater than the value 0.05 . From this reason, we can accept the $\mathrm{H}_{0}$ hypothesis and reject the $\mathrm{H}_{1}$ hypothesis. In this 

V4 Countries

sense, the normality condition is fulfilled and we confirm the normal statistical distribution of the continuous random variable.

In fulfilling the second condition, it was necessary to exclude the extreme values of the variable group, as shown in the following plot box figure.

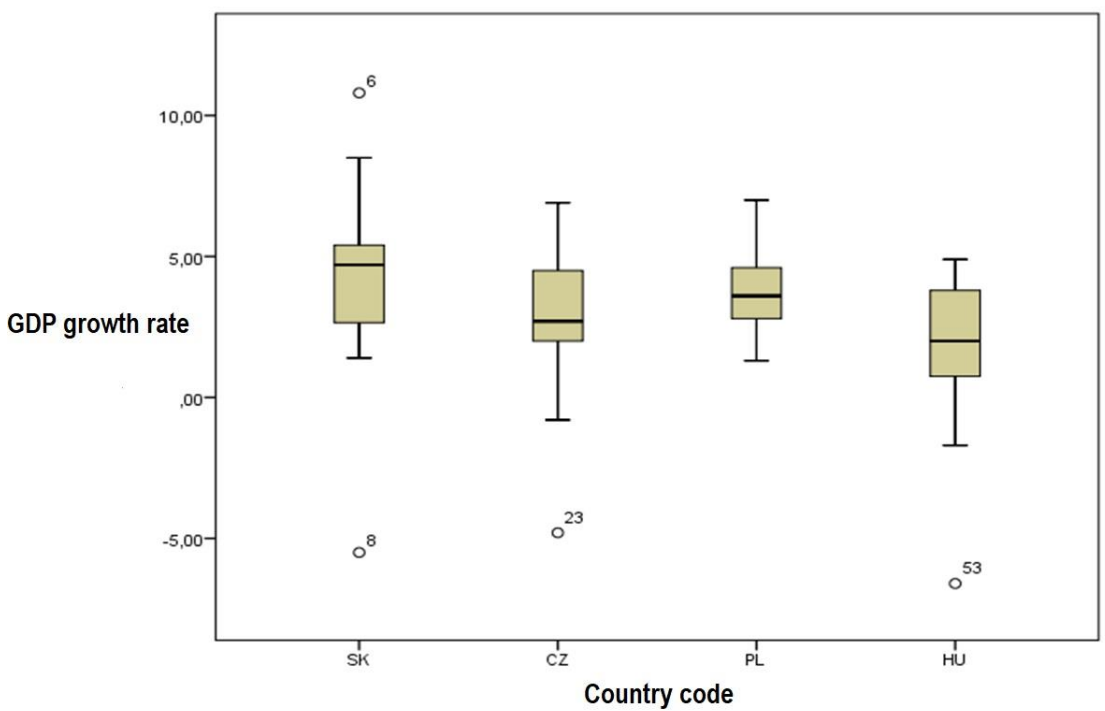

Figure 5. Box plot - GDP growth rate

Source: developed by the authors

All identified deviations that have occurred in relation to Slovakia, the Czech Republic and Hungary, we classify to a set of outlying values, and we can say that there are no extreme values in the set of analyzed variables. Based on this, we conclude that the second condition is fulfilled. In the following investigations, we will also consider outlying values.

Using the variable homogeneity test, we were able to identify whether the variance of the analyzed GDP growth rate variables is equal or different. In this sense, we formulated the hypothesis $\mathrm{H}_{0}$ and the hypothesis $\mathrm{H}_{1}$ :

$\mathrm{H}_{0}$ : There are no significant differences in variance of the analyzed variables, i.e. we consider the variance to be equal.

$\mathrm{H}_{1}$ : There are significant differences in the variance of the analyzed i.e., we do not consider the variance to be equal.

Table 7. Test of homogeneity of variances - GDP growth rate

\begin{tabular}{|l|l|c|c|}
\hline \multicolumn{4}{|l|}{ GDP growth rate } \\
\cline { 2 - 4 } $\begin{array}{l}\text { Levene } \\
\text { Statistic }\end{array}$ & df1 & df2 & Sig. \\
\hline 1.013 & 3 & 56 & 0.394 \\
\hline
\end{tabular}

Source: developed by the authors 
R. Bacik, J. Kloudova, J. Gonos, V. Ivankova. Competitiveness and Performance Based on the Economic Indicators in the V4 Countries

The last third condition, which is to assess the homogeneity of variables, was verified in the previous Table 7. The signification value is 0.394 , which is more than 0.05 . Based on the above, we recommend accepting the $\mathrm{H}_{0}$ hypothesis and rejecting the $\mathrm{H}_{1}$ hypothesis. The variance of the analyzed variables is equal, and therefore the homogeneity of the expansion is fulfilled.

The fulfillment of all three conditions allowed us to apply the ANOVA method also in the case of the analysis of statistical data denoting the economic performance of the V4 countries. In terms of identifying the significant differences in GDP growth rates between the V4 countries, we formulated the $\mathrm{H}_{0}$ and $\mathrm{H}_{1}$ hypotheses:

$\mathrm{H}_{0}$ There are no significant differences in GDP growth rates between the V4 countries.

$\mathrm{H}_{1}$ There are significant differences in GDP growth rates between the V4 countries.

Table 8. Analysis of variances - GDP growth rate

\begin{tabular}{|c|c|c|c|c|c|}
\hline \multicolumn{7}{|c|}{ ANOVA - GDP growth rate } \\
\hline & Sum of Squares & df & Mean Square & F & Sig. \\
\hline Between Groups & 48.555 & 3 & 16.185 & 1.912 & 0.138 \\
\hline Within Groups & 473.951 & 56 & 8.463 & & \\
\hline Total & 522.506 & 59 & & & \\
\hline
\end{tabular}

Source: developed by the authors

Reflecting the outputs of Table 8, we can assert that there is no difference in GDP growth rates between the V4 countries. This is confirmed by the value of the significance of 0.138 , which is more than 0.05. Our recommendation is to confirm the hypothesis $\mathrm{H}_{0}$ and to reject the $\mathrm{H}_{1}$ hypothesis. The analysis did not show a significant difference, and therefore there are no significant differences in GDP growth rates between the V4 countries. Since there was no significant difference, in this case, it was not necessary to use the Bonferroni test.

Conclusion. In a period characterized by economic dynamics, economic growth, the sustainability of economic development, it is common that most countries are concerned with the study of indicators that can help them to understand their economic situation. The article looked at two indicators, namely the GDP growth rate and the Global Competitiveness Index. We analyzed the development and the identified development trend over 15 years of the V4 countries. The countries of the Visegrad Group do not only share a common Central European space, apart from geographic location, but they are also linked with history, culture, values, priorities and interests to strengthen stability in the Central European region. The economic situation of Slovakia, the Czech Republic, Poland and Hungary is more than similar and the countries achieve the same results, in terms of their either economic performance or competitiveness. Each of these economies behaves as an individual living organism, whose behaviour is a reflection of their own needs, priorities and nature of the country's leadership. These countries have always been part of the same civilization based on the same cultural and intellectual values and the common roots of religious traditions. The economic dynamics of the past 15 years, the pressure of economies on sustainable economic development, the strategy and principles of monitoring and managing macroeconomic indicators have affected their diverse economic outcomes. The article focused on the analysis of Global Competitiveness Index variations and the rate of GDP growth as the basic macroeconomic indicators of the V4 countries. The result of the analysis is the existence of differences between countries within the Global Competitiveness Index. In analyzing the rate of GDP growth of countries, the difference has not been demonstrated. The presence of significant differences in the Global Competitiveness Index was most clearly identified in the Czech Republic, which has the best value of this indicator among all V4 countries. This can be justified by the fact that the Czech Republic is bound by strong trade and ownership relations with other European Union countries, the high share of 
the processing industry in the structure of the Czech economy is positively influenced, as well as the long-term low unemployment rate or long-term real convergence towards developed countries. In conclusion, V4 countries are linked by significant factors from social areas, but each country faces different economic problems, which determines their economic status and position in the world. The benefit of the article reflects the perception of the V4 countries from an economic point of view, which is not conditioned by the common characteristics of this group. The analysis absorbs possible skewed speculation and encourages further research that may be dealt with in the future by other macroeconomic indicators within the Visegrad Group.

Author Contributions:Conceptualization, J.K. and V. I.; methodology, R. B.; software, R. B.; validation, J. G. and J. K.; formal analysis, J. K.; investigation, V. I.; resources, J. G.; data curation, J. G.; writing-original draft preparation, V. I.; writing-review and editing, J. G.; visualization, V. I.; supervision, J. K.; project administration, R. B.; funding acquisition, R. B.

Funding:This article is one of the partial outputs under the scientific research grant VEGA 1/0806/16 «Research on issues of consumer behaviour of a new generation of customers with emphasis on identifying preferences and usability of mobile platforms in the process of e-commerce of the subjects localized predominantly on the Central European Market», VEGA 1/0789/17 - «Research of ecommerce with relation to dominant marketing practices and important characteristics of consumer behavior while using mobile device platforms».

\section{References}

Baranik, M. (2003). Teoria a prax hospodarskej politiky. Trencin: TC - TECH. ISBN 80-88914-35-3.

Bartalosova, E. (2015). Rating of Innovation Performance and Competitiveness of the Visegrad Four in Comparison with the EU Member States. 17th International Scientific Conference on Finance and Risk 2015, Bratislava, Slovakia.

Bondareva, I., Tomcik, R. (2015). Porovnanie ekonomického rozvoja Slovenskej republiky a Ceskej republiky na zaklade indexu globalnej konkurencieschopnosti. Scientific Papers of University of Pardubice Faculty of Economics and Administration, 22(33), 6-15.

Bucher, S. (2018). The Global Competitiveness Index As an Indicator of Sustainable Development. Herald of the Russian Academy of Sciences, 88(1), 44-57. doi: 10.1134/S1019331618010082.

Cepel, M., Stasiukynas, A., Kotaskova, A., Dvorsky, J. (2018). Business EnvironmentQuality Index in the SME Segment. Journal of Competitiveness, 10(1): 21-40. DOI: 10.7441/joc.2018.02.02

Despotovic, D., Cvetanovic, S., Nedic, V., Despotovic, M. (2016). Economic, social and environmental dimension of sustainable competitiveness of European countries. Journal of Environmental Planning and Management, 59(9): 1656-1678.doi: 10.1080/09640568.2015.1085370.

Dudas, T. (2012). Vyvoj konkurencieschopnosti statov vysehradskej skupiny v rokoch $2001-2011$ vo svetle medzinarodnych indexov konkurencieschopnosti. Journal of International Relations, 10(2): 58-71. [online, quoted to 02.07.2019]. Retrieved from http://fmv.euba.sk/RePEc/brv/journl/MV2012-2.pdf

Eurostat. (2016). Database. [online, quoted to 02.07.2019]. Retrieved from http://ec.europa.eu/eurostat/data/database

Financial Stability Report 2004. (2005). Bratislava: Narodna banka Slovenska, [online, quoted to 02.07.2019]. Retrieved from http://www.nbs.sk/_img/Documents/ZAKLNBS\%5CPUBLIK\%5CSFS\%5CSFS2004.PDF

Gavurova, B., Vagasova, T., Kovac, V. (2016). Competitiveness Assessment of Slovak Republic Regions. European Financial System 2016. 13th International Scientific Conference of the European Financial Systems. Proceedings of the 13th International Scientific Conference. Ed. Krajicek, J., Nesleha, J., Urbanovsky, K., Brno, 2016, Jun 27 - 28, pp. 175+.

Gavurova, B., Balloni, A. J., Tarhanicova, M., Kovac, V. (2018). Information and CommunicationTechnology in the Role of InformationSystem of HealthcareFacility in the Slovak Republic. ECONOMIES, 6(3), articlenumber 47. doi: 10.3390/economies6030047.

Gordiakova, Z. (2011). Hodnotenie Konkurencieschopnosti Krajin. International Scientific Conference Young Scientists. [online, quoted to 02.07.2019]. Retrieved from http://www3.ekf.tuke.sk/mladivedci2011/herlany zbornik2011/gordiakova zuzana.pdf

Habanik, J., Hostak, P. (2014). The competitiveness of regional economy and regional development. Economic and social development: 8th international scientific conference on economic and social development and 4th eastern European ESD 
R. Bacik, J. Kloudova, J. Gonos, V. Ivankova. Competitiveness and Performance Based on the Economic Indicators in the V4 Countries

conference: Building resilient economy. Varazdin: Varazdin development and entrepreneurship agency with University North, Koprivnica, 34-41.

Ivanova, E., Cepel, M. (2018). The Impact of Innovation Performance on the Competitiveness of the Visegrad 4 Conutries. Journal of Competitiveness, 10(1): 54-72. doi: 10.7441/joc.2018.01.04.

Ivanova, E., Kordos, M., Habanik, J. (2015). The competitiveness of V-4 Countries within the European Union. Actual Problems of Economics, 167(5), 39-49. ISSN 19936788.

Ivanova, E., Masarova, J. (2018). Performance evaluation of the Visegrad Group countries. Economic ResearchEkonomskal strazivanja, 31(1): 270-289. doi: 10.1080/1331677X.2018.1429944.

Kiselakova, D., Sofrankova, B., Cabinova, V., Onuferova, E. (2018). Competitiveness and sustainable growth analysis of the EU countries with the use of global indexes' methodology. Entrepreneurship and Sustainability Issues, 5(3): 581-599. doi: 10.9770/jesi.2018.5.3(13).

Klikova, C. (2015). Competitiveness of Countries in Global Environment. 12th International Scientific Conference on Economic Policy in the European Union Member Countries. Ostravice, Czech republic.

Kljucnikov, A., Krajcik, V., Vincurova, Z. (2018). International Sharing Economy: the Case of AirBnB in Czech Republic. Economics \& Sociology, 11(2): 126-137. doi: 10.14254/2071-789X.2018/11-2/9.

Kocisova, K., Gavurova, B., Behun, M. (2019). Thelmportance of ImplementingEnvironmentalVariables in theProcess of Assessment of HealthcareEfficiencythrough DEA. Ekonomicky casopis, 67(4): 367-387.

Kordalska, A., Olczyk, M. (2016). Global Competitiveness and Economic Growth: A One-Way or Two-Way Relationship? In: Equilibrium-Quarterly Journal of Economics and Economic Policy, 11(1): 121-142. doi: 10.12775/EQUIL.2016.006.

Kotaskova, A., Rozsa, Z. (2018). The Impact of Selected Factors on the Quality of Business Environment Assessment in the Czech Republic and the Slovak Republic. International Journal of Entrepreneurial Knowledge, 6(2): 71-80.

Kotulic, R. (2011). Meranie Makroekonomickej Aktivity pre potreby personalneho manazmentu. - GDP naSlovensku. [online, quoted to 02.07.2019]. Retrieved from http://www.pulib.sk/elpub2/FM/Kotulic15/pdf_doc/kotulic2.pdf

Lisy, J. a kol., 2005. Ekonomia v novej ekonomike. Bratislava: Edicia ekonomia. ISBN 80-8078-063-3

Mokrasova, V., 2008. Makroekonomicky vyvoj, verejné financie a niektoré aspekty konkurencieschopnosti slovenskej ekonomiky. Bratislava: Prognostickyustav SAV. ISSN 0862-9137.

Opreana, A., Mihaiu, D. M. (2011). Analysis of European Union Competitiveness from a new multidimensional model perspective. Romanian Economic and Business Review, 6(4): 68-83. [online, quoted to 02.07.2019]. Retrieved from https://www.pulib.sk:2333/docview/1124438556?accountid=164160

Palkovic, J., Fuskova, M., Sojkova, Z. (2015). Competitiveness of the EU regions: Comparison of the NUTS 2 regions using Regional Index of Competitiveness. Proceedings ICABR 2015: X. International Conference On Applied Business Research. Madrid, Spain, 722-729.

Podobnik, B., Horvatic, D., Kenett, D. Y., Stanley, H. E., (2012). The competitiveness versus the wealth of a country. [online, quoted to 02.07.2019]. Retrieved from https://arxiv.org/abs/1209.2813v1

Samuelson, P. A., Nordhaus, W. D., 2007. Ekonomia. NS SVOBODA. ISBN 80-2050-590-3.

Schwab, K. (2011). The Global Competitiveness Report 2011-2012. Geneva: World Economic Forum. ISBN 13: 978-9295044-74-6. [online, quoted to 02.07.2019]. Retrieved from http://www3.weforum.org/docs/WEF_GCR_Report_2011-12.pdf.

Simionescu, M. (2016). Competitiveness and Economic Growth in Romanian Regions. Journal of Competitiveness, 8(4), 4660. doi: $10.7441 /$ joc.2016.04.03.

Simionescu, M., Lazanyi, K., Sopkova, G., Dobes, K., Balcerzak, A. P. (2017). Determinants of Economic Growth in V4 Countries and Romania. Journal of Competitiveness, 9(1): 103-116. doi: 10.7441/joc.2017.01.07.

Slany, A., (2006). CVKS CR: Konkurencieschopnost' ceské ekonomiky (vyvojové trendy). Brno: Printeco, s.r.o., ISBN 80-2104157-9.

Soosova, V. (2014). Competitiveness of the V4 Countries. Political Sciences, Law, Finance, Economics And Tourism, IV International Multidisciplinary Scientific Conferences on Social Sciences and Arts. Albena, Bulgaria.

Spirkova, D., Kloudova, J., Kljucnikov, A., Stehlikova, B. (2019). Economy Of Heating And Competitiveness Of The State The Link Between The Life Expectancy And The Heating Fuel Type. The Case Of The Slovak Republic. Journal Of Competitiveness, 11(1): 116-134. doi: 10.7441/joc.2019.01.08

Tkacova, A., Gavurova, B., Behun, M. (2017). The Composite Leading Indicator for German Business Cycle. Journal of Competitiveness, 9(4): 114-133. doi: 10.7441/joc.2017.04.08

Visegrad Group. (2017). About the Visegrad Group. [online, quoted to 02.07.2019]. Retrieved from http://www.visegradgroup.eu/about

WEF. World Economic Forum. (2013). The Global Competitiveness Index. [online, quoted to 02.07.2019]. Retrieved from http://www.economy.ge/uploads/ek_ciprebshi/reitingebi/reitingebi_eng/gci.pdf 
R. Bacik, J. Kloudova, J. Gonos, V. Ivankova. Competitiveness and Performance Based on the Economic Indicators in the V4 Countries

Радован Басік, Ph.D., Пряшівський університет (Словаччина);

Ютка Клаудова, Ph.D., Університет підприємничвва та права (Чеська республіка);

Ярослав Гонос, Ph.D., Пряшівський університет (Словаччина);

Вєра Іванкова, Пряшівський університет (Словаччина).

Управління конкурентоспроможністю та економічною ефективністю: досвід країн Вишеградської четвірки

Питанням забезпечення економічної стабільності та підвищення рівня конкурентоспроможності країни приділяється все більше уваги. Авторами зазначено, що у період економічного зростання при аналізі акцент робиться на показниках, які сприяють зміцненню конкурентних позицій країни на світовій арені. Статтю присвячено дослідженню драйверів зміцнення конкурентоспроможності та економічної стабільності країн Вишеградської четвірки (V4) (Словаччина, Чеська республіка, Угорщина та Польща) на основі аналізу двох показників: індексу глобальної конкурентоспроможності та темпу зростання валового внутрішнього продукту (ВВП) за 2002-2016 роки. Авторами зазначено, що країни V4 мають не лише спільне центральноєвропейське розташування, а й пов'язані спільними історичними подіями, культурними особливостями, цінностями, пріоритетами та прагненням до підвищення стабільності у иентральноєвропейському регіоні. Для досягнення поставленої мети, у статті проаналізовано динаміку визначених індикаторів для кожної з країн V4 та порівняно їх із середньостатистичними значеннями у досліджуваній вибірці. Для перевірки висунутої гіпотези застосовано модель ANOVA, що дозволило визначити відхилення від середніх значень кожного з індикаторів у досліджуваній вибіриі. Авторами зазначено, що країни V4 мають схожі тенденції соціального розвитку, при цьому перед кожною окремою країною постають диференційовані за складністю та масштабом економічні проблеми, які визначають конкурентоспроможність кожної країни на світовій арені. Таким чином, отримані емпіричні результати дослідження свідчать про те, що Чеська республіка має найбільще значення за індексом глобальної конкурентоспроможності порівняно з іншими країнами V4. Більще того, доведено, що Чеська республіка є найбільш успішною країною у Вишеградській четвіриі. У статті наголошено, про необхідність подальшого аналізу інших макроекономічних показників розвитку країн Вишеградської четвірки для формування єдиної та збалансованої політики їх розвитку.

Ключові слова: конкурентоспроможність, економічна ефективність, ВBП, Вишеградська група, ANOVA

Manuscript received: 13.06.2019.

(c) The author(s) 2019. This article is published with open access at Sumy State University. 